\title{
NEW MEXICAN GRASSES
}

Jason R. Swallen (1).

The new species of Bromus, Muhlcnbergia, Sporobolus, and Deschampsia here described were among the collections of Efraim Hernández X., Rogers MeVaugh, E. Matuda, and John T. Baldwin, Jr. The types are in the United States National Herbarium.

\section{Bromus cernuus Swallen, sp. nov.}

Perennis rhizomatosus; culmi erecti, $1.8 \mathrm{~m}$. alti; vaginae glabrae, inferiores internodiis longiores, superiores internodiis breviores, suprema elongata; ligula ca. $1 . \mathrm{mm}$. longa, minute ciliata; laminae $25-30 \mathrm{~cm}$. longae, eae culmorum 7-8 mm. latae, glabrae, marginibus scabrae; panicula ca $30 \mathrm{~cm}$. longa, ramis gracilibus ssabris, cernuis, paucifloris; spiculae brevipedicellatae, 4-5-florae; rachilla hirsuta; glumas angustae, acuminatae vel attenuatae, prima 1-rervia, $4.4-5.5 \mathrm{~mm}$. longa, secunda 1-vel 3-nervia, 7.5 - $8 \mathrm{~mm}$. longae; lemma primum $15-17 \mathrm{~mm}$. longum, 5 nervium, basim versus hirtellum, apice dentibus duobus 1 $\mathrm{mm}$. longis praeditum; palea angusta, acuminata, lemmate multo brevior, in carinis scabra; antherae $5 \mathrm{~mm}$. longae.

Perennial; culms erect from short rhizomes, $1.8 \mathrm{~mm}$. tall; lower sheaths longer than the internodes, the upper sheaths shorter than the internodes, the uppermost elongate with a reduced blade, glabrous throughout; ligule less than $1 \mathrm{~mm}$. long, minutely ciliate; blades 25 - 30 (m. long, those of the culm $7-8 \mathrm{~mm}$. wide, of the young shoots $2-4$ $\mathrm{mm}$. wide, glabrous on both surfaces, the margins scabrous; panicle about $30 \mathrm{~cm}$. long, the slender, scabrous, drooping branches in distant pairs, bearing a few distant rather short-pedicellate spikelets; spikelets $2-3 \mathrm{~cm}$. long including the awns, 4- or 5-flowered, the joints of the rachilla hirsute; glumes narrow, acuminate or attenuate, the first 1-nerved, 4.5-5.5 mm. long, the second 1-or 3-nerved, 7.5-8 mm. long, lemma of first floret 15-17 mm. long, 5-nerved, the intermediate nerves less prominent, hirtellous toward the base, the apex with 2 slender teeth about $1 \mathrm{~mm}$. long; awn $8-15 \mathrm{~mm}$. long, hirtellous; palea narrow, acuminate, much shorter than the lemma, scabrous on the keels; anthers vellow, $5 \mathrm{~mm}$. long.

i) Department of Botany, United States National Museum, Smithsonian Institution. 


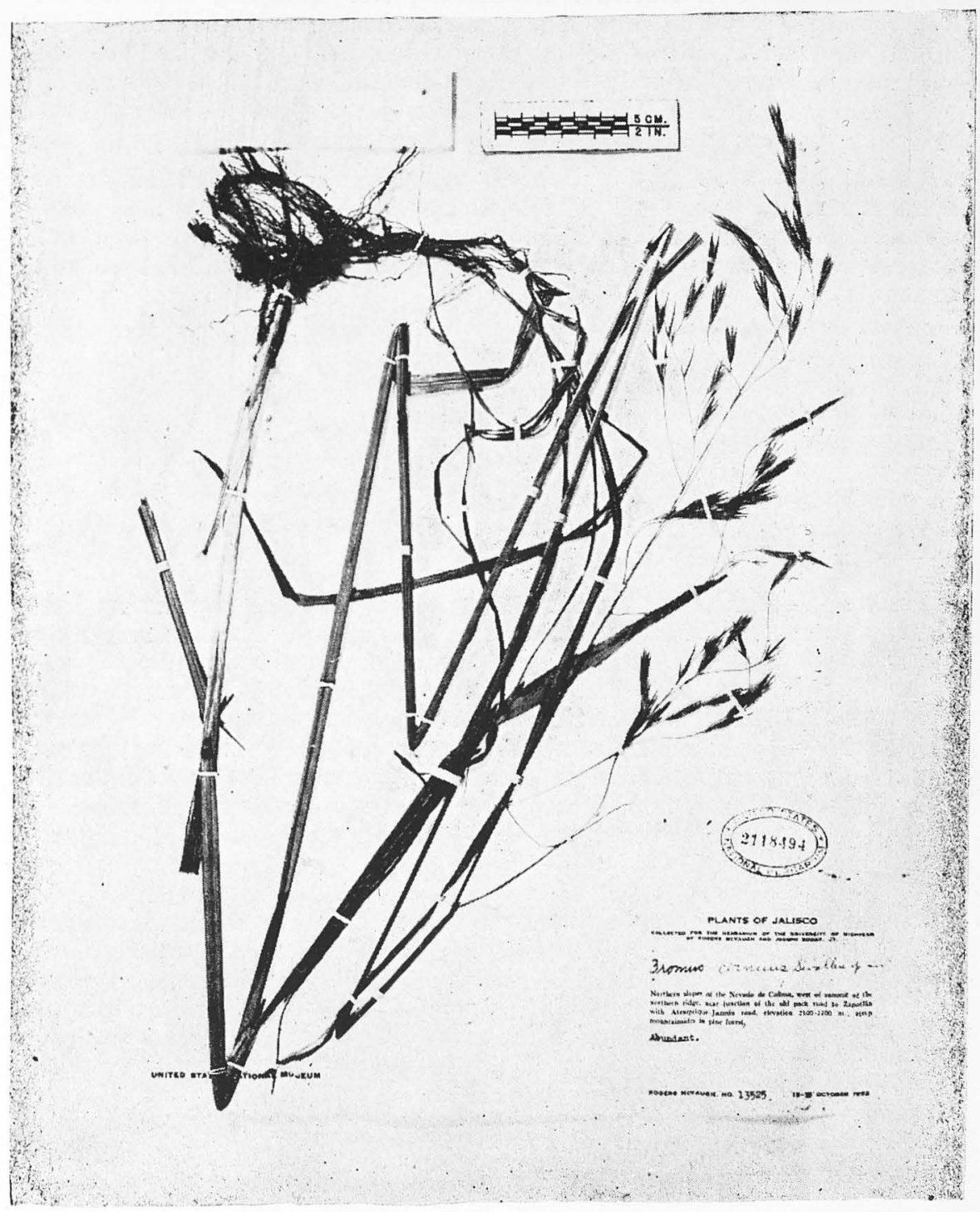

Fig. 1.-Bromus cernuus Swallen sp. norv. 
Type in the U.S. National Herbarium, No. 2,118,494, collected on steep mountain sides in pine forest, northern slopes of the Nevado de Colima, west of summit of the northern ridge, near junction of the old pack road to Zapotlán with Atenquique-Jazmín road, 2100-2200 m. altitude, Jaliseo, México, October 15, 1952, by Rogers VeVaugh (No $13525)$.

This species is related to Bromus densus Swallen which differs in having a small, dense, erect panicle, densely hirsute lemmas, and much narrower, pilose blades. It is abundant on mountain slopes in pine and fir forests at altitudes of 2000 - 2600 meters, in the states of Jalisco and Michoacán.

Other specimens examined: Jalisco: Santa Mónica, MeVaugh 14079; El Isote, above Jazmín. MeVaugh 10108. Sierra de Manantlán, abont 2 miles from Aserradero San Miguel Uno, MeVaugh 13869. Michoacán: Road from Pátzcuaro to Tacámbaro, Moore, Hernández \& Porras 5581. Volcán de Paricutín, Sohns 817; 8?6.

Deschompsia mexicana Swallen, sp. nov.

Perennis; culmi erecti ca. $1 \mathrm{~m}$. alti, foliosi; vaginae internodiis longiores, glabrae; ligula $0.5 \mathrm{~mm}$. longa, minute ciliata; laminae usque ad $30 \mathrm{~cm}$. longae, $3-4 \mathrm{~mm}$. latae, attenuatae, glabrae vel supra pilosae; panicula $16 \mathrm{~cm}$. longa, ca $3 \mathrm{~cm}$. lata, aliquantulum densa, ramis anguste adscendentibus, fasciculatis, inferioribus $6 \mathrm{~cm}$. longis; spiculae 3-florae, suprema reducta; glumae acuminatae, subaequales, prima 1-nervia, secunda 3-nervia; lemma primum 4-4.5 mm. longum, scaberulum, callo dense pilosum pilis $1 \mathrm{~mm}$. longis, apice 4-dentatum dentibus setaceis; axista $7-8 \mathrm{~mm}$. longa, super basim 1/4 inserta, geniculata, infra geniculum contorta.

Perennial; culms erect, about $1 \mathrm{~m}$. tall, leafy; sheaths mostly longer than the internodes, glabrous; ligule $0.5 \mathrm{~mm}$. long, minutely ciliate; blades as much as $30 \mathrm{~cm}$. long, $3-4 \mathrm{~mm}$. wide, firm, attenuate, glabrous, or pilose on the upper surface, the margins more or less scabrous, panicle $16 \mathrm{~cm}$. long, about $3 \mathrm{~cm}$. wide, rather dense, the branches narrowly ascending, fasciculate, those of the lowest fascicle $6 \mathrm{~cm}$. long with shorter ones intermixed; spikelets 3-flowered. the upper often rudimentary, the rachilla pilose, the hairs $1-2 \mathrm{~mm}$. long; glumes acuminate, subequal the first 1-nerved, the second 3-nerved; lowest flopet $4=4.5 \mathrm{~mm}$. long, the callus densely pilose, the hairs about $1 \mathrm{~mm}$. long. the lemma scaberulous, terminating in 4 setaceous teeth, bearing a geniculate awn inserted $1 / 4$ above the base, $7-8 \mathrm{~mm}$. long, tightly twisted below the bend. 


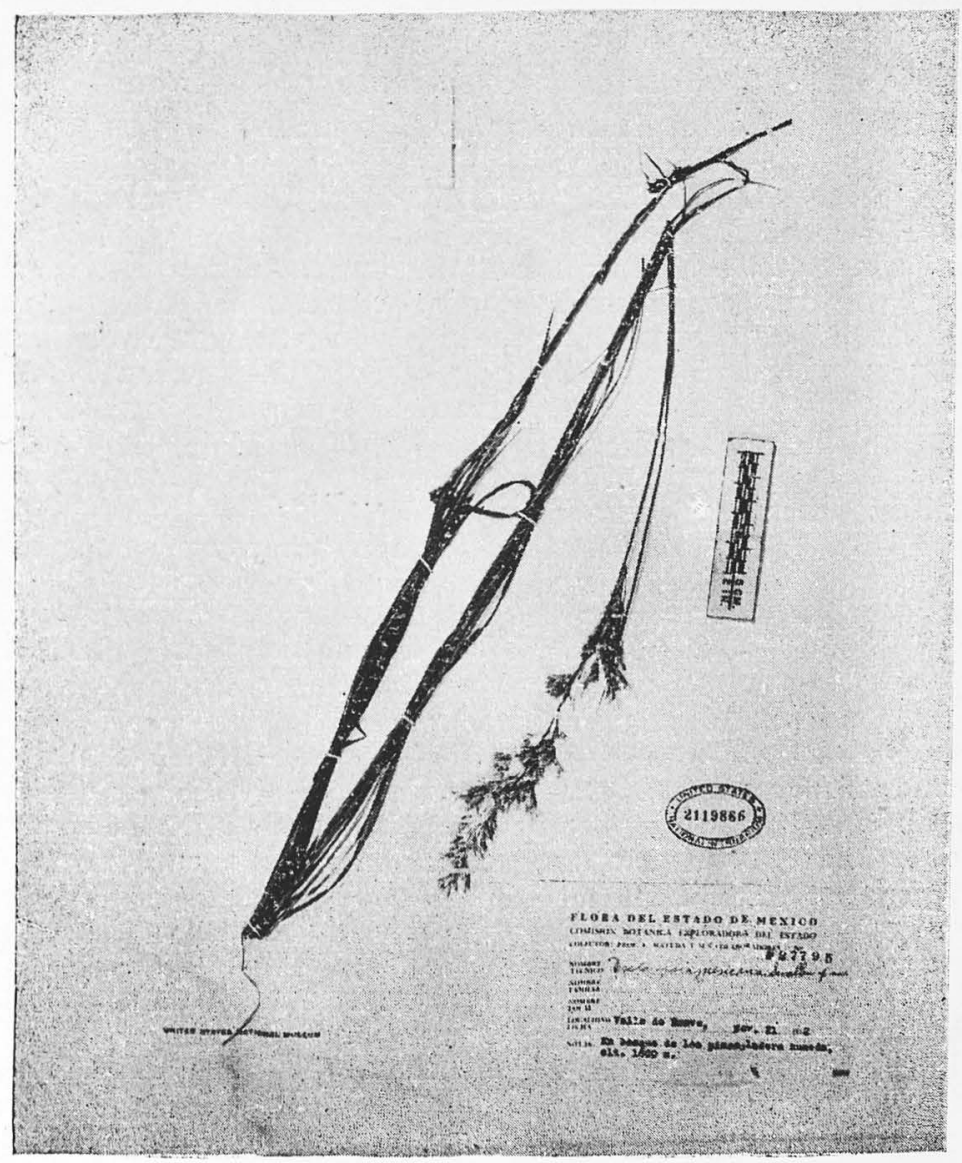

Fig. 2. Deschampsia mexicana Swallen sp. nov. 
Type in the U. S. National Herbarium, No. 2,119,866, collected "En bosque de los pinos, ladera húmeda. Valle de Bravo, 1800 m. alt.", state of México, México, November 21, 1952, by E. Matuda (No. 27,795).

Probably related to Deschampsia straminea Hitche, but readily distinguished by the tall leafy culms with flat elongate blades, and the setaceous teeth of the lemma.

\section{MLuhlenbergia brevivaginata Swallen, sp. nov.}

Perennis caespitosa; culmi gracillimi, erecti, 28 - $40 \mathrm{~cm}$. alti, glabri; vaginae $1.3-3 \mathrm{~cm}$. longae internodiis multo breviores, glabrae; ligula hyalina, acuminata, $2-3 \mathrm{~mm}$. longa; laminae subfiliformes, involutae, glabrae, $5-14 \mathrm{~cm}$. longae, suprema reducta ca. $1 \mathrm{~cm}$. longa; panicula $1-3 \mathrm{~cm}$. longa, angusta, pauciflora, ramis paucis brevibus plus minusve flexuosis; spiculae 4-5 mm. longae; glumae acutae, prima $1.4-2 \mathrm{~mm}$ longa, secunda 2.5-3 mm. longa; lemma basi dense pilosum, aristatum, arista gracili $5-8 \mathrm{~mm}$. longa; palea lemmate paulo brevior, acuta.

Cespitose perennial; culms very slender, erect, 28 - $40 \mathrm{~cm}$. tall, glabrous; sheaths 1.3-3 cm. long, much shorter than the elongate internodes, glabrous, the basal sheaths, becoming shredded with age; ligule hyaline, acuminate, $2-3 \mathrm{~mm}$. long, decurrent; blades subfiliform, involute, glabrous, $5-14 \mathrm{~cm}$. long, the uppermost reduced, about $1 \mathrm{~cm}$. long; panicle 1 - $3 \mathrm{~cm}$. long, narrow, few-flowered, the few short slender, often flexuous branches bearing one or two spikelets; spikelets 4 -5 mm. long, dark gray-green; glumes acute, the first 1.4-2 mm. long, the second $2.5-3 \mathrm{~mm}$. long; floret densely pilose at the base, the lemma tapering into a slender awn $5-8 \mathrm{~mm}$. long, the palea a little shorter than the lemma, acute, somewhat divergent from the lemma.

T'ype in the U. S. National Herbarium, No. 2,118,495, collected in grassy openings in open forest of Quercus macrophylla, on shallow soil over gently sloping rocks, road to Maseota, 6 miles northwest of Crautla, 1850 meters, Jalisco, México, October 21, 1952, by Rogers McVaugh (No. 13671).

This delicate species seems not to be closely related to any known species. The very short sheaths, the few-flowered panicles of grayish green spikelets, and the palea gaping from the lemma, identify it.

Muhlenbergia decumbens Swallen, sp. nov.

Annua; culmi gracillimi, decumbentes, usque ad $25 \mathrm{~cm}$. longi, glabri, ramosissimi; vaginae glabrae, plerumque internodiis ca, $1 / 2$ breviores; ligula hyalina $2 \mathrm{~mm}$. longa; laminae $1-6 \mathrm{~cm}$. longae, $0.6-1 \mathrm{~mm}$. 


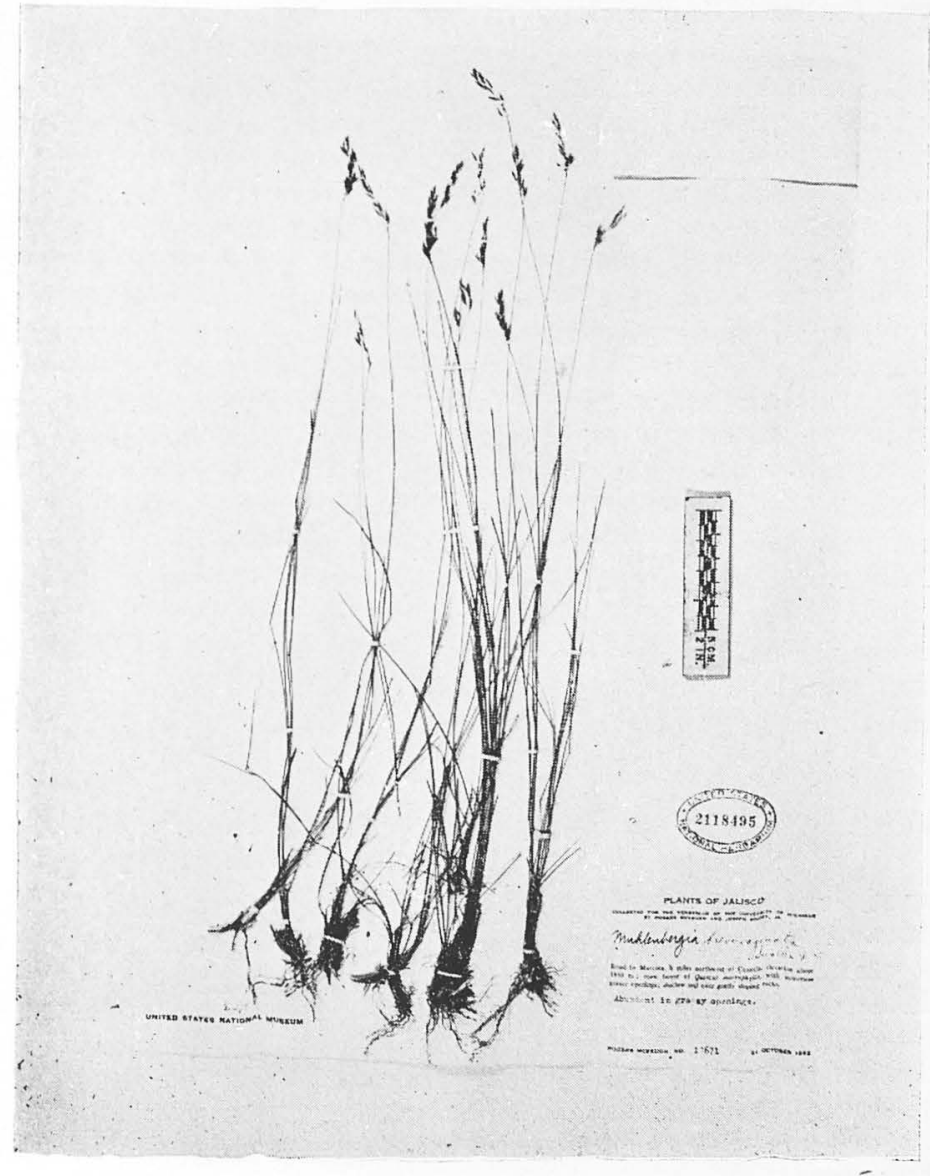

Fig. 3.-Muhlenbergia brevivaginata Swallen sp. nov. 
latae; panicula $1.5 .7 \mathrm{~cm}$. longa, ramis adscendentibus vel appressis usque ad $3 \mathrm{~cm}$. longis; spiculae brevipedicellatae, appressae, $3-3.5 \mathrm{~mm}$. longae; glumae acuminatae, $1.5-3 \mathrm{~mm}$. longae, secunda prima paulo longior; lemma glabrum vel marginibus sparse pilosum, aristatum, ariset $1-2 \mathrm{~mm}$. longa; palea lemma subaequans, nervis in aristis brevibus productis; antherae $1 \mathrm{~mm}$. longae.

Annual; culms very slender, weak, decumbent spreading, as much as $25 \mathrm{~cm}$. long, glabrous. freely branching from all the nodes, the branches erect or ascending; sheaths glabrous, mostly about half as long as the internodes; ligule hyaline, about $2 \mathrm{~mm}$. long; blades $1-6 \mathrm{~cm}$. long, 0.6-1 mm. wide; inflorescence 1.5.7 cm. long, the branches as cending or appressed, in the larger inflorescences as much as $3 \mathrm{~cm}$. long, with one or two short, appressed, secondary branches; spikelets shortpedicellate, appressed, $3-3.5 \mathrm{~mm}$. long, not including the awn; glumes acuminate or awn-pointed, $1.5-3 \mathrm{~mm}$. long, the second a little longer than the first; lemma tapering into an awn $1-2 \mathrm{~mm}$. long, glabrous or sparsely pilose on the margins: palea nearly as long as the lemma, the nerves extending into short awns; anthers $1 \mathrm{~mm}$. long.

Type in the U.S. National Herbarium, No. 2.237.023, collected on "ori1la carretera, suelo migajón arenoso gris, km. 83, Cuauhtémoc-V. Guerrero, 2200 m.", Chihuahua, México, October 27, 1954, by E. Hernández X. and C Tapia J. (No. N-359).

This species is closely related to Muhlenbergia subbiflora Hitche. which has smaller spikelets, $2-2.5 \mathrm{~mm}$. long. larger anthers, $1.5 \mathrm{~mm}$. long, and thinner, usually acute, not at all awn-pointed glumes.

\section{Muhlenbergia jaliscana Swallen, sp. nov.}

Perennis caespitosa; culmi erecti $1.3 \mathrm{~m}$. alti; vaginae glabrae vel plus minusve pilosas, suprena elongata; ligula firma, $1-4 \mathrm{~mm}$. longa; laminae usque ad $50 \mathrm{~cm}$. longae, basi involutae, apicem versus planae, $3 \mathrm{~mm}$. latae, supra nervosae, scabrae; panicula $30 \mathrm{~cm}$. longa, ramus gracilibus, scabris, adscendentibus vel patentibus, irferioribus $12-14 \mathrm{~cm}$. longis; spiculae 6-6.5 mm. longae; glumae $2-2.5 \mathrm{~mm}$. longae, acutae vel subobtusae, secunda prima paulo longinr; lemma callo dense pilosum ceterum glabrum; arista $1.2 \mathrm{~cm}$. longa, gracilis, scabra, plus minusve flexuosa

Densely cespitose perennial; culms erect, $1.3 \mathrm{~m}$. tall; leaves crowded at the base, the culm naked except for a single elongate sheath; sheaths rounded, glabrous or more or less pilose in lines; ligule firm, 1. $4 \mathrm{~mm}$. long; blades as much as $50 \mathrm{~cm}$. long. usually eurved or flexuous, narrower at the base than the mouth of the sheath, the margins inrolled, 


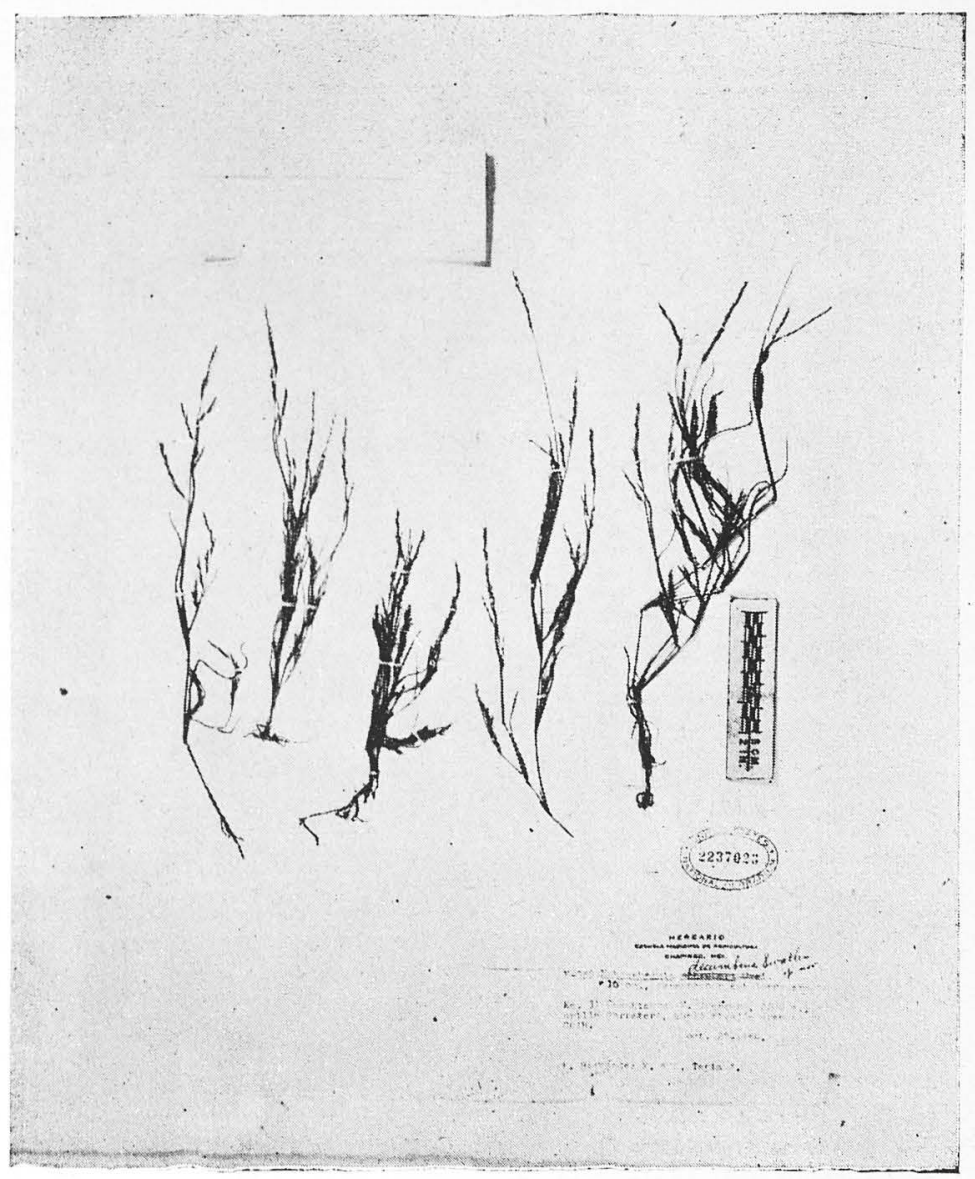

Fig. 4.-Muhlenbergia decumbens Swallen sp. nov. 


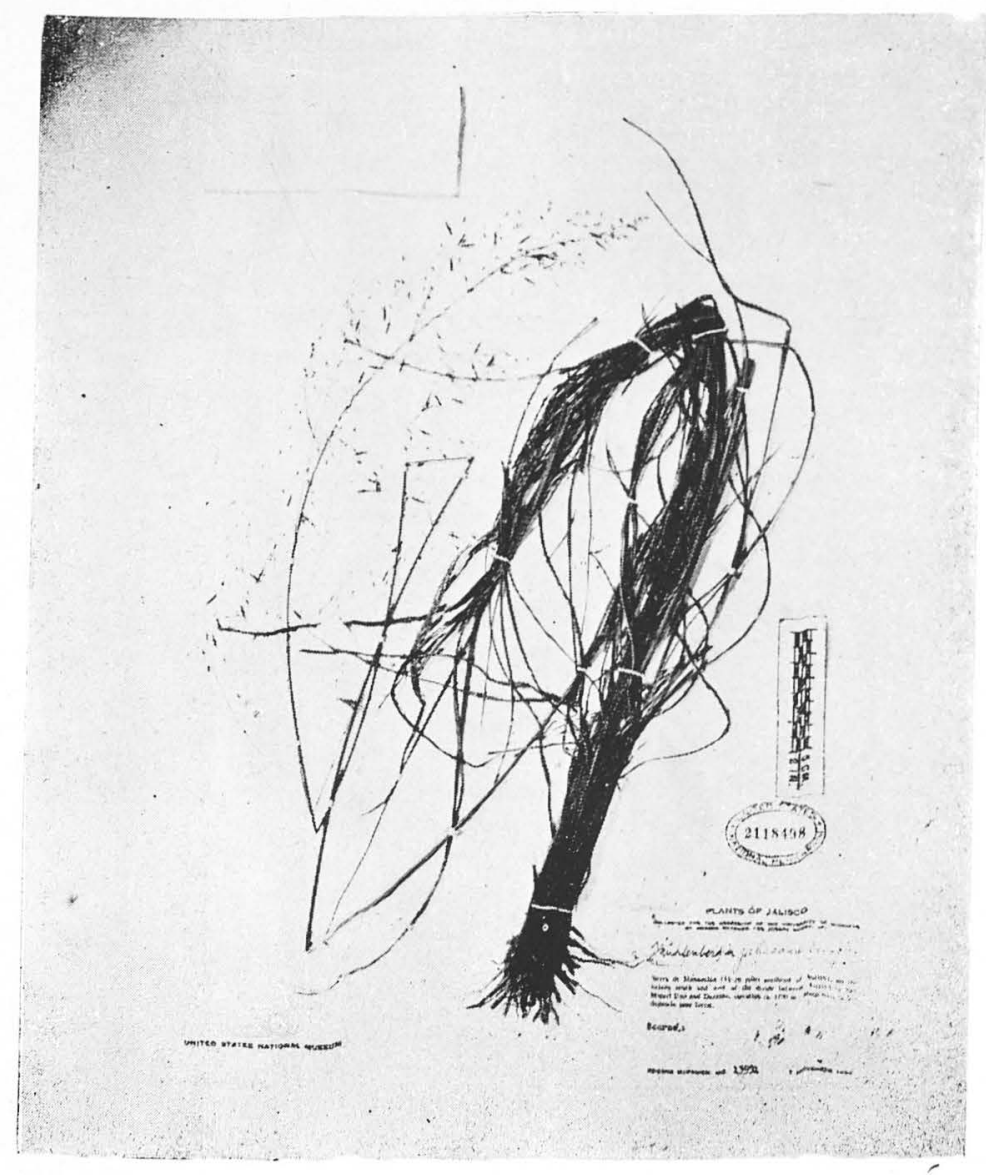

Fig. 5.-Muhlenbergia jaliscana Swallen sp. nov. 
becoming flat upward, as much as $3 \mathrm{~mm}$. wide, strongly nerver and very scabrous on the upper surface; panicle $30 \mathrm{~cm}$. long, narrowly pyramidal, the slender, scabrous branches ascending to spreading, the lowcrmost $12-14 \mathrm{~cm}$. long, with a few scattered stiffly ascending to spreading few-flowered branchlets; spikelets $6-6.5 \mathrm{~mm}$. long; glumes $2-2.5$ mm. long, acute or subobtuse, the second a little longer than the first; floret rather densely pilose on the callus, otherwise glabrous, the lemma tapering into a slender scabrous, more or less flexuous awn $1-2 \mathrm{~cm}$. long, the palea acuminate, nearly as long as the lemma.

Type in the U.S. National Herbarium, No. 2,118,498, collected on the steep west-facing slopes in pine forest, Sierra de Manantlán (15 - 20 miles southeast of Autlán), on the "bajada" south and west of the divide between Aserradero San Miguel Uno and Durazno, 1700 m., Jaliseo, México, November 7, 1952, by Rogers McVaugh (No. 13,991).

This species is probably most closely related to Muhlenbergia reverchoni Vasey \& Scribn., which has shorter spikelets about $5 \mathrm{~mm}$. long, with a short straight awn $2-5 \mathrm{~mm}$. long; the panicle is more fragile, and the blades shorter, almost always closely involute.

\section{Sporobolus splendens Swallen, sp. nov.}

Perennis robustus; culmi ca. $2 \mathrm{~m}$. alti, erecti, duri; vaginae internodiis multo longiores, glabri; ligula ca. $0.5 \mathrm{~mm}$. longa, minute ciliata; laminae durae, elongatae, attenuatae, basi ca. $1 \mathrm{~cm}$. latae, canaliculatae, spicem versus planae, basin versus supra longipilosae, marginibus glabrae vel scabrae; panicula erecta, densa, purpurea, $50 \mathrm{~cm}$. longa, ramis numerosis, gracilibus, erectis vel adscendentibus, scaberulis, inferioribus usque ad $15 \mathrm{~cm}$. longis; spiculae $1.8-2 \mathrm{~mm}$. longae; pedicelli spiculis rlerumque multo breviores; glumae acutae vel subobtusae, in carina scabrae, variables, prima fosculo ca $1 / 2$ brevior, secunda paulo longior vel flosculum subaequans; lemma subobtusum, glabrum.

Very coarse perennial; culms about $2 \mathrm{~m}$. tall, erect, about $6 \mathrm{~mm}$. thick toward the base (excluding the sheaths), hard, woody; sheaths much longer than the internodes, rounded, not at all keeled, smooth; glabrous; ligule about $0.5 \mathrm{~mm}$. long, minutely ciliate; blades elongate attennate, about $1 \mathrm{~cm}$. wide at the base, gutter-shaped, hard and thickened along the midnerve, long-pilose on the inner surface, becoming flat and glabrous some distance from the base, the lower surface smooth, glabrous, the margins glabrous or scabrous; panicle erect, dense purple, $50 \mathrm{~cm}$. long, the numerous slender branches erect or ascending, spikeletbearing to the base or nearly so, the lower ones as much as $15 \mathrm{~cm}$. long; spikelets $1.8-2 \mathrm{~cm}$. long, the pedicels usually much shorter than the 


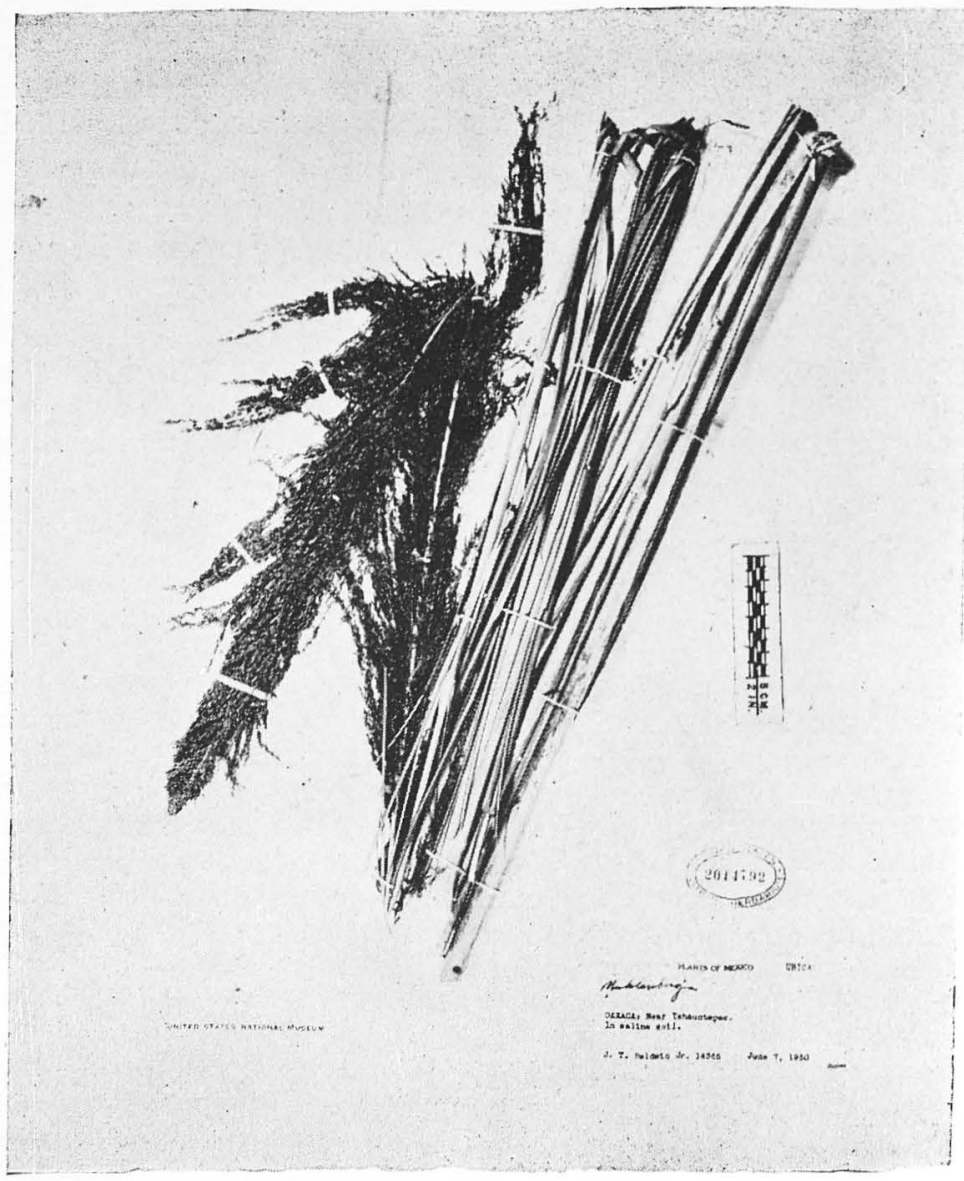

Fig. 6.-Sporobolus eplendens Swallen sp. nov. 
spikelet; glumes acute to subobtuse, variable in length, the first usually about half as long as the floret, the second a little longer to nearly as long as the floret; floret glabrous.

Type in the U. S. National Herbarium, No. 2,014,792, collected in saline soil near Tehuantepec, Oaxaca, México, June 7, 1950, by John T. Baldwin, Jr. (No. 14,365). More recently this species has been collected by Hernández X. and Miranda (No. 270), at km. 840 on the PanAmerican highway, east of Tehuantepec, about $40 \mathrm{~m}$. altitude, in a wet savanna with Sabal where it is the dominant plant forming large clumps as much as $1.5 \mathrm{~m}$. tall.

This striking species is easily recognized by the very firm channeled blades and the large panicle of small purple spikelets. 